\title{
Common Property Resources Synergy and Perspectives of Sustainable Management in Garurganga Watershed, Indian Central Himalaya
}

\author{
B. K. Joshi \\ G. B. Pant Institute of Himalayan Environment and Development, Kosi-Katarmal, \\ Almora 263 643, Uttaranchal, India \\ E-mail: bkjoshi_alm@rediffmail.com
}

KEYWORDS Common Property Resources. Farming Community. Synergy. Management. Indian Central Himalayas

\begin{abstract}
Keeping in view the pivotal role of common property resources in hill farming system an effort was made to review the ongoing resources management of three major Common property resources (land, water and forest) in the representative villages of Bhetagad- Garur Ganga watershed, Indian central Himalayas. Based on field experiences and review of the resources synergy, it is strongly advocated that the management and conservation of common property resources must be framed, implemented and evaluated in the light of area specific needs, socioeconomic characteristics, bio-physical attributes and the influence of external forces. Thus it is urgently required that the management of common property resources could be ensured by maintaining harmony between man and nature.
\end{abstract}

\section{INTRODUCTION}

Common Property Resources (CPRs) play pivotal roles for the livelihood of the people in the mountains region, including the Himalayan hills where their livelihood mostly depends in (subsistence) marginal agriculture. The farming system of the Himalayan middle mountain is governed by availability of CPRs i.e. forest, water and pasture land (Gadgil and Iyer, 1989; Chopra et al., 1990. Most of the natural resources of the region have been using various to meet their dayto-day needs, and in maintaining the ecological balance between the resources and socio economic status. Economic status of the inhabitants is around a holistic and complex network of livestock, cultivable land, forests and water. However, unscientific harvesting and mismanagement of these resources have been deteriorating severely, ultimately ecological imbalance raised between man natural resources (Joshi, 2002). The high rate of deforestation, expansion of agriculture land and demand of fuel and fodder has further accelerated the rate of environmental degradation of these natural resources in the region (Gaur and Silas, 1985; Shah, 1986).

Still some work done so far to mitigate the common property resources management for the survival strategies of the poor in the mid hill of Indian Central Himalayas (Jodha, 1986, 1992; Wade, 1987) are ultimately meant of the betterment of the people. Thus to develop best possible option of farming systems have required a tandem with the local communities in order for improving their livelihood strategies (Sharma and Kumar, 2002). Thus the participatory action research might be contribute towards better quality of life in mountain conditions through suggesting sustainable measures with scientific rigour, integrated strategies, and participatory approach for the better management of CPRs for ensuring the livelihood security, Access equity and conflict resolution and resource conservation. The present study reviewing the ongoing management practices related to the three major Common property resources (i.e., forest, pasture and water) in 5 villages. The plan formulation for the bottom up approach on joint planning, execution and monitoring on management and conservation of major CPRs of this region, has also been incorporated in the present paper.

\section{Study Area}

The study related to CPRs management was carried out in 5 representative villages of Garur Ganga watershed in Uttaranchal state of India. The study watershed falls between $29^{\circ} 50^{\prime} 23^{\prime \prime}$ to $29^{\circ} 55^{\prime} 56^{\prime \prime} \mathrm{N}$ and $79^{\circ} 29^{\prime} 59^{\prime \prime}$ to $79^{\circ} 38^{\prime} 04^{\prime \prime}, \mathrm{E}$ which covers an area of about $83 \mathrm{Km}^{2}$ in Uttaranchal Himalayas. The watershed having 63 villages with a total population of 14524 
(Census, 1991), consisting of Brahman, Rajputs (higher casts) and Harijans (SCs, lower casts), which are placed hierarchically in terms of social stratification. The per capita cultivable land and livestock units in the watershed is 0.13 hectare and 0.70 units, respectively whereas, it was found 0.12 hectare and 0.53 units respectively in 5 studied villages. The village economy is characterised by subsistence agriculture, mainly on rainfed conditions. All agriculture operations are still performed by local breed of bullocks while buffalos, cow, goats are the major cattle types establishing link between forest, agriculture and the people Chir pine (Pinus roxburghii) is the major forest species, occupying over $70 \%$ of the total forest area. In the studied watershed the forest area covered $60.65 \%$ of total geographical area and dominated by Chir Pine (Table 1). Broad-leaved species like Quercus leuchotrichophora (Banj), Q. glauca (Phalyant), Alnus nepalensis (Utish) and a few patches of Rhododendrum arboreum (Burans) Myrica esculanta (Kafal) in mixed as well as in the form of a few small pure patches in upper and mid of the watershed. After the independence of the India republic the community composition showed tremendous changes in the traditionally marked Zajmani relations for exchange of different socio-economic services. The representative villages have significant variations in terms of community structure/ and composition, altitudinal variations, geographical

Table 1: Details of synergy parameters considered for CPRs review

\begin{tabular}{|c|c|}
\hline Synergy parameters & Factors \\
\hline The People & $\begin{array}{l}\text { Population, number of } \\
\text { household's and Caste } \\
\text { composition. }\end{array}$ \\
\hline $\begin{array}{l}\text { Status of existing } \\
\text { common properties resources }\end{array}$ & $\begin{array}{l}\text { Forest, water resources, } \\
\text { pasture lands, wasteland } \\
\text { etc }\end{array}$ \\
\hline Geophysical Characteristics & $\begin{array}{l}\text { Altitude, geographica } \\
\text { area, slope, distance from } \\
\text { the road head and } \\
\text { Blockhead quarter. }\end{array}$ \\
\hline Economic status & $\begin{array}{l}\text { Per capita cultivable land, } \\
\text { per capita livestock units, } \\
\text { Percent of irrigated land, } \\
\text { household income etc. }\end{array}$ \\
\hline $\begin{array}{l}\text { Accesses and management } \\
\text { system }\end{array}$ & $\begin{array}{l}\text { Access to essential } \\
\text { amenities and infra- } \\
\text { structure, adoption rate } \\
\text { and interventions by } \\
\text { modified traditional } \\
\text { knowledge. }\end{array}$ \\
\hline
\end{tabular}

area, distance from road head, per capita cultivable land, livestock units, status of CPRs, and access to essential amenities and infrastructure. Detailed information on status and management of CPRs was collected as a secondary data through tested interview scheduled, formal/ informal meetings and discussions, participants and non participant's observations, PRA and group discussions.

\section{METHODOLOGY}

The prelimineary surves were conducted in the Garur Ganga watershed. Based on these primary surveys, 5 villages were selected from the watershed for the intensive study of common property resources synergy, Table (2) and Table (3).

\section{RESULTS AND DISCUSSION}

Community Forest: In the rugged hill of the Indian Central Himalayas the community forests, pasture degraded land and water resources have been considered as major CPRs based on utilization patterns and traditional management practices. They constitute fragile ecosystems prone to undesirable consequences at the slightest disturbance due to geological geomorphological, hydrological etc. conditions. The grand old management practices of these forestlands perform both production and protection functions and it is futile to argue over the relative importance of each type of forest categorized by farming community. The Community, which constitutes about $7.0 \%$ of the total forest area (Saxena, 1995) is one of the most important CPRs for 4808 villages to meet their demand of fuel and fodder. As per management and practices these community forest system may be further categorised into following categories.

Sanjayathi Van: The Sanjayathi vans are unique and very old traditional community forest systems of the study area. The farming communities have an equal stakes and equal right to protect and utilization of such forests. Such Sanchayathi Van obviously controlled by village community by the support of the state Government, in study watershed is predominated by Pinus roxburghii (Chir pine) and occupy over $70 \%$ of the total forest cover. Some villages have their local institutional management to manages these natural resources are least affected from grazing, forest fire and quarrying of forest product 
results of that these forest produced superior quality grasses (without sharp panicle) and enhance the yield as well. The perceptions of farming community in behind of these practices are to grow good quality of grasses for milching cattles in lean period as a fodder bank. Further more, due own management systems these forests are harvested at the end of kharif when the user groups completely free from their cropland.

The grass/fodder products of the Sanchayati Vans is done adopting lottery system and harvesting right is given after deposition of an amount towards cost of grass vary from Rs. 30/ - to Rs. 100/-depending upon the size and productivity of particular plots. In exceptional cases the slip (harvesting right) may be sold to the other bonafied households if one does not need the grasses. However the by products i.e. leaf litter used for cattle bedding and mulching could be collected by these stockholders by paying the free or a nominal amounts.

The Sanchayati Van has an elected body for management, including the charging penalties in any offence, e.g., illegal felling of trees and within Sanchayati Van. Further, the villagers are also entitled to get the timber from the forest for repair/maintenance and construction of new house, on nominal cost. A significant part of the revenue collected by the van Panchayat is being spent on annual maintenance/ protection and management aspect of the Panchayat van area. However, a small amount is used for community welfare programmes, depending on requirement and decision made by Van Panchayat in its general body meeting.

Khula Van: The Khula vans (open forests) are allocated on steep ridges and are one of the most exploited natural resource in the region are prone to highest soil erosion, landslides and natural calamities. These forest bearing immense biotic pressures in terms of grazing throughout the year, litter collection, forest fire and queering activities by farming community. Thus the community people know how they may be used to these steep slope locating forest resources for gaining least by-products in the form of fodder for non-milching cattles, fuel wood and timber during the entire year.

Bajyani: The Bajayani (oak dominated small patches) is a combined property of a village community/ more than 10-15 households or some times an individual farmer managed broadleaved tree species patches along with superior quality of grasses and used for fodder purposes in the watershed area. Most of the cases the Bajyani having broad leaf species such as Oak (Quercus leuchotrichophora) dominated along with Utees (Alnus nepalensis), Bheemal (Grewia optiva), Phalyant (Quercus glauca), Kanol (Bauhinia retusa), Kweral (Bauhunia verigater), Timil (Ficus roxburghii), Kafal (Myrica esculanta), Khareek (Celtis sp.), Padam (Prunus cerasoides) and Burans (Rhododendron arboreum) species. As per perceptions of the grand old men of the farming communities such broad leaved patches are unique sources of fodder in dry period (November-March) because these are least damaged by frost. Beside this the communities protect to such type of patches to enhancing the water yield whenever these patches located in catchment area of the springs. Still the farming community shows keen interests to develop such type of broad-leaved forest patches in abundant land of the watershed.

Pasture Land: The grassland/pasture lands are cereal in nature having originated consequent to deforestation and abandoned cultivation and most of the cases are intermixed with big or small patches of open forest. Further, it is vary difficult to classify the pastures because both type of lands (pasture and degraded) are open for grazing and due to over exploitations of grazing of pasturelands during past have gradually been converted in to degraded patches. In this region the livestock farming almost depends on these grassland specially in lean period however the pasture land are widely used for grazing of the cattles for entire the year. The field visit experiences/ observations and discussions with the villagers it was found that the factors influencing the management of Common Property resource may be classified broadly into two categories; 1 . The socio-economic factors i.e., composition of village community, economic inequality, gender issues, level of infrastructure development, lack of participation, cumbersome systems and policies, funds driven programmes, and mass ignorance, intrusions and encroachments and institutional weakness; 2 . The biophysical factors i.e., land degradation, availability and access to alternative resources, and availability of resources within and outside the village boundary. These grassland/pasture lands may further categorized as following as per their management systems and utility for the community people. 
Taana: The Taanas (protected grasslands) are key sources of fodder for the livestocks of the region and fulfilling the about 6 to 8 months fodder in the year, mainly in the form of dry grasses. In general it occurs in the form of big fragmented grass cultivation area in upper ridges of watershed, such as in case of village Doba, Table -2 , where the entire village community benevolent of the land. Some time this may be a property of the inhabitants of more than one village. These grasslands are well-maintained results of that producing good quality and quantity of grasses for livestock during the entire year.

Kanaie: The Kanaies (partially protect grassland) are basically lying in form of small patches (below than 10 ha area) and is a share land of small group of farmers. In general such type of landforms allocating in upper and mid altitude of the watershed. The farming community protected to these patches in peak of monsoon (July - October) and rest of the season used for open grazing. This grassland patches producing comparatively lower yield of grasses and is with very low number of grasses or herbs species than the protected grassland. Basically these lands are nutrient deficient and produced sharp panicles grasses species. Even though such types of grasslands are inferior sources of fodder but the farming community want to produce maximum yield of grasses by the short time site protection along with as grazing in dry period. Other perceptions of the farming peoples, the dry period grazing is quite helpful to produced good yield of grasses in very short span.
Maang: The maangs are small grassy patches are the functions of abundant cultivated terraces with good terrace bunding. These patches are joint families/ farmers property and it covers an area about smaller than 1.0 ha. Generally such types of land patches are widely spread in the each zone of the watershed. Due to wellmaintained nature of these terraces, there are least possibility of erosion losses and results of that providing a certain good quality of grasses species than above two categories of grassland patches. Some time such types of land are also used for horticultural activities along with grass production.

Charagah: The Charagah (grazed lands) are the results of regular grazing of the mismanaged grassland patches and are highly denuded sites in the watershed. In general these lands are also results of highly fragmented grassland and the management of such type of land is very difficult to manage for grass cultivation or other purpose. The farming community perceptions behind to manage such land resources to keep it as open for grazing, that they shift their workload of fodder for non-milching cattles in these grazed lands. The high nutrient deficiency in such land produced almost sharp panicle grasses through the year which sufficient to live the non-milching cattles.

Water Resources: In the Indian central Himalayan region, 'Until the State Government had enforced 'Kumaun Water Rules: 1917, water was considered as "property of every one" and had been used as first come first serve. At present, study watershed is governed by 'Kumaun

Table 2: Details of users and status of main CPR in representative villages of Garurganga watershed

\begin{tabular}{|c|c|c|c|c|c|c|c|}
\hline Village & $\begin{array}{c}\text { Total } \\
\text { population }\end{array}$ & $\begin{array}{c}\text { Total } \\
\text { number of } \\
\text { house hold }\end{array}$ & $\begin{array}{c}\text { Caste wise } \\
\text { household } \\
\text { s distribution } \\
\text { (B-R-SC- } \\
\text { Other) }\end{array}$ & $\begin{array}{l}\text { Land under } \\
\text { community } \\
\text { forest }\end{array}$ & $\begin{array}{c}\text { Land } \\
\text { available } \\
\text { under CPR }\end{array}$ & $\begin{array}{c}\text { Drinking } \\
\text { water } \\
\text { facilities }^{* *}\end{array}$ & $\begin{array}{c}\text { Percentage of } \\
\text { irrigated land to } \\
\text { total cultivable } \\
\text { land }\end{array}$ \\
\hline Doba & 216 & 38 & $10-22-6-0$ & 80.2 ha & $\begin{array}{l}\text { 41.4 ha (PL) } \\
10.1 \text { ha (WL) }\end{array}$ & $\begin{array}{l}\text { Springs } 03 \text {, } \\
\text { Tap x } 04\end{array}$ & NA \\
\hline Laubanj & 702 & 113 & $15-71-27-0$ & 24.6 ha & $\begin{array}{l}8.094 \text { ha (PL) } \\
6.412 \text { ha (WL) }\end{array}$ & $\begin{array}{l}\text { Springs } 4 \text {, } \\
\text { Tap 08 }\end{array}$ & 41.5 (Govt. canal) \\
\hline Patli & 630 & 108 & $71-1-36-0$ & 13.3 ha & $\begin{array}{l}4.202 \mathrm{Ha}(\mathrm{PL}) \\
5.281 \mathrm{ha}(\mathrm{WL})\end{array}$ & $\begin{array}{l}\text { Springs 07, } \\
\text { Tap 06 }\end{array}$ & , 25.5 (Govt. canal) \\
\hline Kafaldunga & 481 & 75 & $0-10-0-65$ & 07.7 ha & $\begin{array}{l}0.927 \text { ha (PL) } \\
\text { 5.084ha (WL) }\end{array}$ & $\begin{array}{l}\text { Springs } 06 \text {, } \\
\text { Tap } 07\end{array}$ & 6, 89.1(Trad. Gool) \\
\hline Bimola & 358 & 68 & $0-0-68-0$ & Nil & 6.202 ha (PL) & $\begin{array}{l}\text { Springs } 1 \text {, } \\
\text { Tap } 5\end{array}$ & 79.8 (Govt. canal \\
\hline
\end{tabular}

PL - refer to pasture, WL - refer to waste land and NA-Not available

Source: * Office of the Block Development Officer - Garur and ** Primary Survey 2001. 
Aur Garhwal Jal Sangrah, Sanchay Ewam Vitaran Rules: 1975 (Kumaun and Garhwal Water Collection, Storage and Distribution Rule: 1975). Traditional Naula, Dhara (natural spring) and the introduced tap supply are vital sources of drinking water, Table-3. The access to the water resource is governed by typical mechanisms of access, community composition, availability of water resources, caste conflicts etc. Farmers having free irrigation water and using to it first come first serve basis. In few villages the village community still follows their traditional water distribution regime called 'Sanchayati Gool' (community canal). Irrigation water use is governed by a common mechanism applicable for entire community, irrespective of the cost and religion while access to a particular source is governed by traditional use rights, traditional use rights may be flexible or rigid, depends on community structure and ownership of a particular piece of land where water spring on naula is silvated. The management and use is based on mutual understanding and agreed upon mechanism developed among the villagers. In general the high ridge locating villages such as Doba there is spring water are the sources of drinking and irrigation water as well. However the mid locating villages i.e. Laubanj and Patali with higher number of drinking water and moderate availability of irrigation water. The low land locating villages having sufficient water for drinking and irrigation.

\section{Management Strategies}

Initiation of Land Management Programs:
In the Bhetagad watershed community forestry and pasture land management by community participations might be contribute towards meeting the demand of good quality fodder and income generating sources for the inhabitants. The Albiziza stipulata, Dalbergia sissoo and Alnus nepalensis are fast growing leguminous trees that are believed to increase the soil fertility levels. Besides this, Grewia optiva and Quercus leucotrichophora species are also important for meet the fodder, fuel demand and other uses.

\section{Strategies for Water Management}

As per water resources synergy experienced and review for five representative villages of Garurganga watershed it is urgently required to initiate some innovations and tested options for drinking and irrigation water management i.e. water conservation, harvesting, people participation with line agencies and alternate cropping, which might be, restore to soil water and fed to these water bodies. Keeping in view the undulating topographic, geo-hydrological and socio-economic conditions the following water conservations innovations are beneficial in irrigation water management of the region.

A. Re-Vegetation in Water Resources Catchment Area: Plantation of species such as Qurecus, Bhaunia, Alnus etc. considered ecologically sustainable and helpful to conserve the soil and water losses. These steps may help to maintain the water availability in terms of land restoration and down stream water discharge improvement in the study area. In the recharge area and water infiltration can be induced or

Table 3: Synergy matrix of CPRs in representatives' villages of Garurganga watershed

\begin{tabular}{lccccc}
\hline $\begin{array}{l}\text { Common property } \\
\text { resources } \\
\text { community forest }\end{array}$ & \multicolumn{5}{c}{ Name of representative villages } \\
\cline { 2 - 6 } & Doba & Patali & Luabanj & Kafaldhunga & Bimola \\
\hline Khula Van & HA & MA & MA & MA & NA \\
Sanjayati Van & MA & NA & MA & MA & NA \\
$\begin{array}{l}\text { Bajyani } \\
\text { Grass/Pastureland }\end{array}$ & MA & NA & MA & NA \\
Taan & MA & NA & NA & NA & NA \\
Kanie & HA & MA & MA & MA & NA \\
Maang & HA & MA & MA & MA & NA \\
Water Resources & MA & MA & HA & HA & MA \\
Springs & MA & MA & MA & MA & HA \\
Drinking water supply & NA & MA & MA & MA & MA \\
Irrigation canal & & &
\end{tabular}

NA- refers to not available, MA- refers to marginally available and HA- refers to highly available 
increased through engineering and biological methods. These practices also helpful to enhancing the stream water demand particularly for that stream, which shows diminishing due to drying up of spring throughout the populated belts.

B. Water harvesting Techniques: Under the water harvesting techniques only three possibilities were observed which might be sustainable as suggested for the rain fed watershed; (i) Waste water harvesting, (ii) Rainwater harvesting, and (iii) Roof water harvesting. Out of these the waste water technique might be helpful to fulfill the demand in dry spell of winter and summer as well however the rain and roof water harvesting techniques are quite helpful reducing the evaporation rate in dry period in mid and bottom of the watershed as observed for all three categories of water harvesting.

\section{Active Mass Awareness Program}

Under present circumstances, the land and water resource restoration has urgently required in the watershed area. However a strong collaboration is needed in between the inhabitants, NGOs and local institutions and concerning Govt. line agencies. The local institutions i.e. Pani Panchyath (Water managing committee), Nav Yuwak Managal Dal (youth development groups) and as far as Mahila Mangal Dal (women development groups) has to need to supported technically and financially as well.

\section{Tested Options for Alternate Cropping}

Thus keeping in view the over exploitation of CPRs in the study villages there has an urgent need to use the alternate options as per availability and demand of the resources in the watershed area. The upland villages might be encouraged to develop the community forest and pasture land for producing good quality of fodder product along with low crop water requirement agro-crops. However the mid and bottom locating villages has need to encourage the high crop water requirement crop species/ cash crops along with fish farming. Thus fish farming is completely restricted prohibited in upper zone of the watershed. Thus the inhabitant of upper zone of the watershed might be exchanges their fodder product with agro-crops/cash crops of mid and low land locating villages by Zazmani system or by paying the cost of the products.

\section{CONCLUSION}

The study concludes that the higher exploitation of common property resources become a threat for longevity of such resources. Thus there need for appropriate management practice is essential to conserve to these CPRs by suitable measures as required for each category of CPRs. The people centered approach might be ensuring sustainable, balanced and equitable development of the area. The socioeconomic aspects and their indicators seem highly relevant for better understanding of sustainable management and utilization of CPRs.. This exercise can well be used in other water sheds of Indian central Himalayas i.e. Capacity building, strengthening of local institutions, essential policy amendments PRA, Decentralised policies and programme formulation at micro-level, Creating awareness, ensuring effective and massive involvement of women along with maintaining harmony between man and nature.

\section{ACKNOWLEDGMENTS}

Author is grateful to the Director, G.B. Pant institute of Himalayan Environment and Development, Kosi-Katarmal, Almora (UA) for providing facilities.

\section{REFERENCES}

Anonymous, District Census Hand Book- Almora, Census of India, Part - B1951-(1991).

Chopra, K. Kadekodi, G. K. and Murty, M. N.: Participatory Development: People And Common Property Resources. Sage Publication India Pvt. Ltd., New Delhi. (1990).

Gadgil, M. and Iyer, P.: On the diversification of common property resource use by Indian society. pp. 24055. In: Common Property Resources. Fikret Berkes (Ed.). International Book Distributors, Dehradun (1989).

Gaur, R. D., Silas, R. A. and Prohit, V. P.: Landuse patterns and settlements in the Benu valley in Garhwal Himalaya. Mountain Research and Development, 5(3): 91-94 (1985).

Jodha, N. S.: Common property resources and rural poor in dry region of India. Economic and Political Weekly, XXI (27): 1169-81(1986).

Jodha, N. S.: Common property resources. A missing dimension of development strategy. World Bank 
Discussion Paper 169, World Bank, Washington DC. (1992).

Joshi, B. K.: Effect of landuse and elevation on soil properties of Bhetagad Watershed- A case study from Indian Central Himalaya. Journal of Soil and Water conservation, 1(2and3): 109-117 (2002).

Shah, S. L.: Planning and Management of Natural and Human Resources in the Mountains- A Micro Level Approach With Special Reference to Central Himalaya. Yatan Publications Delhi (1986).

Saxena, N. C.: Towards Sustainable Forestry in the U.P.
Hills. Uttar Pradesh Forest Department, Overseas Development Administration U.K. (1995).

Sharma, R. J. and Kumar, A.: 'Livestock care and management options in Watershed management. Pp. 199-208 In: Watershed Management in Himalaya - Concept and Strategy. B. P. Pande (Ed.), Gyanodaya Prakashan, Nainital (2002).

Wade, R.: The management of common property resources: Collective action as an alternative to privatisation or state regulation. Cambridge Journal of Economics, 11: 95-106 (1987). 